Food, Dairy and Home Economic Research

http:/www.journals.zu.edu.eg/journalDisplay.aspx?Journalld=1\&queryType=Master

\title{
EFFECT OF ADDING Spirulina platensis IN PASTA PRODUCTS (SPAGHETTI)
}

\author{
Mahmoud K. Abd El-Hameed*, S.M. Abou El-Maatti, Soheir M.E. El-Saidy \\ and Somaya M. Ahmed
}

Food Sci. Dept., Fac. Agric., Zagazig Univ., Egypt

Received: 16/11/2017 ; Accepted: 05/12/2017

\begin{abstract}
Spirulina platensis can be regarded as an alternative and promising food ingredient due to their nutritional composition, richness in bioactive compounds, and because they are considered a sustainable protein source for the future. The objective of this study was to prepare fresh spaghetti enriched with different amounts of Spirulina platensis and to compare the fatty acid profile of spaghetti before and after cooking, with standard semolina spaghetti. The results showed that fatty acid profile of spaghetti prepared with Spirulina platensis incorporation, presented a high resistance to the thermal treatment applied during the cooking procedure. Increase the amount of Spirulina platensis lead to increase of fatty acids both in raw and cooked spaghetti.
\end{abstract}

Key words: Spirulina platensis, spaghetti, fatty acids.

\section{INTRODUCTION}

Pasta is favoured by consumers for its versatility, ease of transportation, handling, cooking and storage properties, availability in numerous shapes and sizes, high digestibility, good nutritional qualities and relatively low cost. Therefore, pasta can be used as carrier of specific compounds. It is traditionally manufactured from durum wheat semolina (Rakhesh et al., 2015). Durum wheat semolina is the base material for spaghetti, fusilli, and other pasta products. Semolina is processed by adding water, extruding the dough into the desired shape - which gives its characteristic flavour and drying it under well controlled conditions to prevent the development of cracking. Dry pasta is basically made of starch granules uniformly dispersed in a continuous protein phase known as gluten. When pasta is extruded in long cylindrical shape with a diameter between 1 and $2 \mathrm{~mm}$ it is given the commercial name of spaghetti (Guinea et al., 2004). In recent years, different healthy ingredients have been used in the production of pasta to enhance its nutritional profile or to functional properties. However, the amount of raw material that can be used as a substitute for wheat flour or can be added to wheat flour represents a compromise between nutritional improvement and satisfactory sensorial properties of pasta (Chillo et al., 2008).

The commercially produced multicellular microalgae, Spirulina platensis, is widely consumed by humans in the Aegean area of Turkey as a food additive or a whole food (Diraman et al., 2009). When the algal cells or filaments of spirulina are transformed into powder it can provide the basis for a variety of food products, such as soups, sauces, pasta, snack foods (Vonshak, 1990). Spirulina itself or its components including fatty acids omega-3 or omega-6, beta carotene, alpha-tocopherol, phycocyanin, phenol compounds effective to treat certain allergies, anemia, cancer, hepatotoxicity [toxicity of the liver], viral and cardiovascular diseases, hyperglycemia [high blood sugar], hyperlipidemia [high cholesterol and triglycerides], immunodeficiency, and inflammatory processes (Chamorro et al, 2002). Spirulina platensis is a rich source of vitamins, antioxidants and $\gamma$-Linolenic (GLA) with medicinal and nutritional values (Belay, 2002).

\footnotetext{
* Corresponding author: Tel. : +201222281859

E-mail address: Mkhairy@yahoo.com
} 
$\gamma$-linolenic acid (GLA) is a commercially important polyunsaturated fatty acid (PUFA), is effective in lowering plasma cholesterol and in stimulating prostaglandins and has been used as a dietary supplement for the treatment of various chronic health problems (Kay, 1991). GLA has also been found to be an important nutrient for the prevention of certain skin disorders, such as psoriasis (Ziboh and Fletcher, 1992). GLA is being found useful in the treatment of arthriti (Belch et al., 1988). Three major bioactive components of Spirulina, the protein phycocyanin, sulfated polysaccharides, and $\gamma$-linolenic acid (GLA) seem to play significant roles in imparting improved human body functionsthe available clinical evidence does not indicate a serious risk to health or other public health concerns due to Spirulina (Dan and Kamilkuca, 2016).

The aim of the present study is to prepare spaghetti enriched with different amounts of Spirulina platensis $(0.5,1.0$ and $2.0 \mathrm{~g} / 100 \mathrm{~g}$ DW) as natural source of fatty acid, and to compare their fatty acid profile before and after the cooking process, in order to conclude about their stability to the thermal process. The effect of this incorporation on the sensorial attributes of the pasta was also evaluated.

\section{MATERIALS AND METHODS}

\section{Spirulina platensis Production}

Spirulina used in this study was isolated from El-Khadra Lake (Wadi El-Natrun) Spirulina was cultivated in Zarrouk's medium (Zarrouk, 1966). Semi continuous cultivation was carried out in two-liter Erlenmeyer flasks containing an initial volume of 1.8 litres of Zarrouk's medium and an initial S. platensis biomass concentration of $0.15 \mathrm{~g} / \mathrm{l}$. Aeration was accomplished using diaphragm pumps to produce a flow rate of 20 1/hr., of air (Costa et al., 2002) and $40 \mathrm{~W}$ fluorescent lamps provided an illuminance of 2500 lux.The whole apparatus at $30^{\circ} \mathrm{C}$ with a $12 \mathrm{hr}$., light/dark photoperiod (Vonshak et al., 1982). When the $S$. platensis biomass concentration in the culture reached a predetermined level $(0.50$ or $0.75 \mathrm{~g} / \mathrm{l})$ a portion of the medium ( 25 or $50 \%(V / V)$, was removed and the same amount of fresh medium added, each experiment being with the duration of about 90 days $(2160 \mathrm{hr}$.). Each day samples were collected aseptically and frozen and then freezdrying.

\section{Fresh Pasta Production}

Fresh pasta was produced from commercial durum semolina flour, water and Spirulina platensis at $(0.5,1.0$ and $2.0 \mathrm{~g} / 100 \mathrm{~g} \mathrm{DW})$ and without Spirulina platensis as a control sample. The mixture was extruded as spaghetti $(1.5 \mathrm{~mm}$ diameter, $200 \mathrm{~mm}$ length) using a benchtop pasta maker (Biffinet, Verona, Italy). Different pasta treatments were dried at $60^{\circ} \mathrm{C}$ for $5 \mathrm{~min}$, until final moisture of 30-32 g/100 g. Ten gram of each pasta was cooked in $100 \mathrm{ml}$ boiling distilled water until optimum cooking time, considered as the time necessary to obtain complete gelatinization of starch, shown by the disappearance of the white central core, after having pressed the spaghetti strand between two transparent glass slides (Edwards et al., 1993; Tudorica et al., 2002; Brennan et al., 2003).

\section{Chemical Composition}

The major biochemical constituents such as crude protein, ash, lipids, carbohydrates and moisture content were determined in Spirulina platensis from El-Khadra Lake (Wadi ElNatrun). Total protein was determined by the conventional Micro- Kjeldahl method (AOAC, 2000). The moisture and ash were determined according to AOAC (2000). Total carbohydrate contents of Spirulina platensis were determined according to the Renol- Reaction method of (Gerhardt et al., 1981), total lipids were extracted from Spirulina platensis dry weight according to (AOAC, 2000). Using Soxhelet method apparatus. Fatty acid methyl esters (FAMEs) of the total lipid were prepared by transesterifiction using 2\% sulphuric acid in methanol (Christie, 1993). The fatty acid analysis was done by gas chromatography (Perkin Elmer Auto System xl) equipped with flame ionization detector and DB5silica capillary colum (60 $\mathrm{m} \times$ $0.32 \mathrm{~mm}$ i.d.), the oven temperature was maintained initially at $45^{\circ} \mathrm{C}$ and programmed to $60^{\circ} \mathrm{C}$ at a rate $1^{\circ} \mathrm{C} / \mathrm{min}$, then it programmed from $60^{\circ} \mathrm{C}$ to $240^{\circ} \mathrm{C}$ at a rate $3^{\circ} \mathrm{C} / \mathrm{min}$. Helium was used as the carrier gas at flow rate $1 \mathrm{ml}$ $/ \mathrm{min}$. the injector and the detector temperatures were set at $230^{\circ} \mathrm{C}$ and $250^{\circ} \mathrm{C}$, respectively.

\section{Sensory Analysis}

A sensory evaluation of the fresh spaghetti containing Spirulina platensis, as well as the control semolina spaghetti, was conducted in order to evaluate the impact of Spirulina 
platensis on the sensory properties. Fifteen untrained individuals (six men and nine women, aged between 28 and 45) were asked to indicate colour and resistance to break of uncooked spaghetti and adhesiveness. Colour, odour and taste were evaluated for cooked samples (Padalino et al., 2013). To this aim, a nine-point scale, where 1 corresponded to extremely unpleasant, 9 to extremely pleasant and 5 to the threshold acceptability, was used to quantify each attribute (Petitot et $\boldsymbol{a l}$., 2009 a and b). On the basis of the above-mentioned attributes, panellists were also asked to score the overall quality of the products using the same 1-9 scale.

\section{RESULTS AND DISCUSSION}

\section{Spirulina and Spaghetti Composition}

The chemical composition of freeze-dried Spirulina platensis was determined and the results are presented in Table 1. The protein content of Spirulina platensis in this research was $53.92 \%$ and carbohydrate valued $18.10 \%$ which are higher than previous research by Madkour et al. (2012) which were only $52.10 \%$ for protein and $10.61 \%$ for carbohydrate content, respectively and the component of moisture $8.2 \%$ and fat $6.67 \%$ are higher than the same previous research which valued $7.66 \%$ and 1.48\%. Alvarenga et al. (2011) found that spirulina protein content represented 58.2\%, however higher protein content $69.2 \%$ were obtained by Mbaiguinam et al. (2006) in spirulina from kanem lake Chad. Piorreck et al. (1984) reported that increasing the nitrogen level in the nutrient medium leads to an increase in the biomass and protein content in spirulina. The major fatty acids (\% of total fatty acids) in raw and cooked control spaghetti and enriched with $0.5,1.0$ and 2.0 Spirulina platensis spaghetti were carried out and the results are presented in Tables 2 and 3. The main concern in the present study was the occurrence of polyunsaturated fatty acids (PUFA) in spaghetti with Spirulina platensis. (PUFA) have a significant nutritional importance. The enrichment of spaghetti with $0.5,1.0$ and 2.0 Spirulina platensis lead to the occurrence of $\gamma$-Linolenic acid (GLA) in spaghetti before and after cooking (Tables 2 and 3). While, $\gamma$-Linolenic acid (GLA) was absent in spaghetti without Spirulina platensis (control). In testing both chlorella and Spirulina for GLA it was found that Spirulina had "unusually high levels of GLA, an essential polyunsaturated fatty acid." (Otles and Pire,
2001). The increase of the amount of Spirulina platensis lead to increase of fatty acids (C16:0, Palmitic acid; C17:0, Margaric acid; C18:0, Stearic acid; C18:1, Oleic acid; and C18:3, $\gamma-$ Linolenic acid) both in raw and cooked spaghetti.

\section{Sensory Evaluation}

Spaghetti prepared with addition of $(0.5,1.0$ and $2.0 \mathrm{~g})$ Spirulina platensis is presented in (Figs. 1 and 2). Spaghetti enriched with Spirulina platensis had an appealing colour, increasing colour intensity with concentration (Fig. 1). The colour of Spirulina platensis spaghetti remained relatively stable after cooking (Fig. 2). The addition of Spirulina platensis resulted in an increase in the raw pasta firmness when compared to the control sample.

Table 4 shows the results of sensory evaluation of Spirulina platensis spaghetti samples. Sensory results highlight that all spaghetti samples recorded a positive overall quality score. In particular, spaghetti enriched with (1.0 g Spirulina platensis) had the highest, mainly due to an improved resistance to break and colour. On the contrary, spaghetti enriched with (2.0 g Spirulina platensis) showed the smallest overall quality score as compared to the other samples. Some individuals detected a strange flavour (fish flavour) in the spaghetti prepared with $2.0 \%$ which were the samples that also obtained lower scores for the attributes of odour and taste.

\section{Conclusions}

Spaghetti product was successfully produced by adding Spirulina to semolina flour. Spaghetti prepared with Spirulina presented a chemical composition richer than the control in fatty acids especially Palmitic acid, Oleic acid and $\gamma$ Linolenic acid (GLA).

Spirulina platensis spaghetti presented very appellative colors, such as orange and green, similar to pastas produced with vegetables, with nutritional advantages. The use of Spirulina platensis can enhance the nutritional and sensorial quality of pasta, without affecting its cooking and textural properties.

The textural characteristics of the spaghetti, namely firmness, are positively affected by the inclusion of Spirulina, when compared to the control. The increase of spaghetti firmness may be related to the addition of components rich in protein that, probably have a significant influence in the reinforcement of the gluten network. 

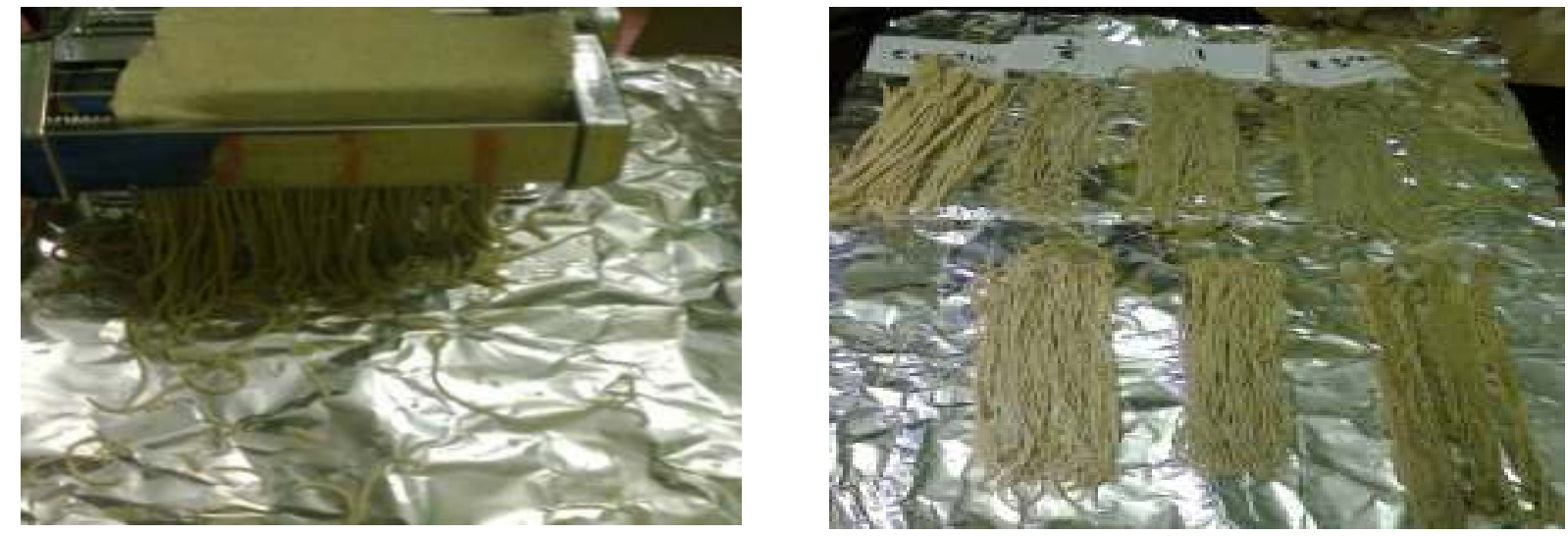

Fig.1. Preparation of spaghetti enriched with (0.5, 1.0 and 2.0 g/100 g DW) Spirulina platensis

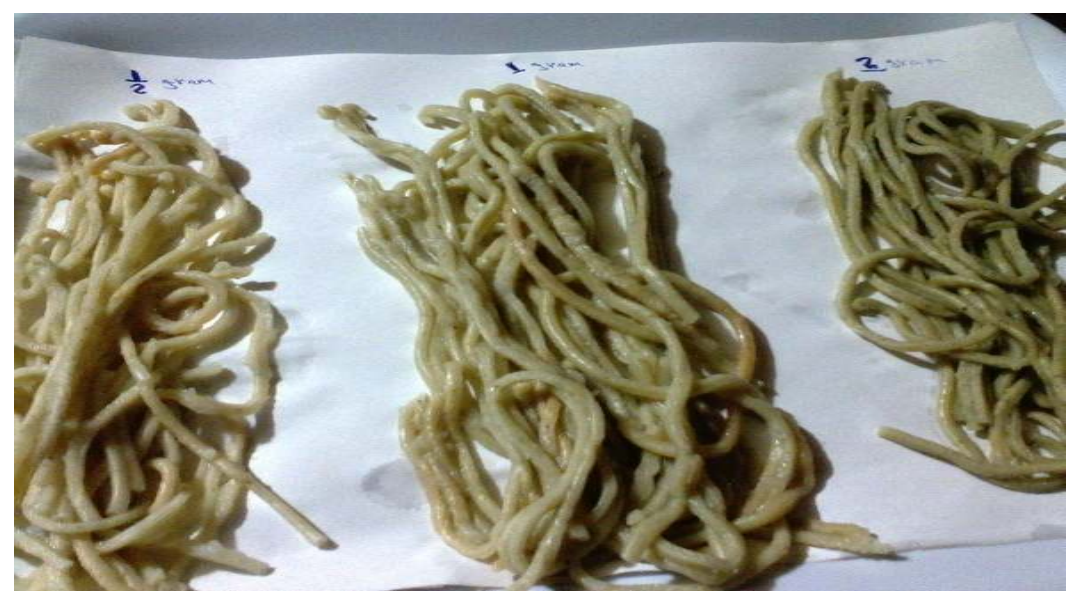

Fig. 2. Spaghetti enriched with (0.5, 1.0 and $2.0 \mathrm{~g} / 100 \mathrm{~g}$ DW) Spirulina platensis after cooking

Table 1. The chemical composition of freeze-dried Spirulina platensis

\begin{tabular}{lc}
\hline Content & Chemical composition (\%) ( Mean \pm S.E) \\
\hline Moisture & $8.2 \pm 0.04$ \\
Crude protein & $53.92 \pm 1.21$ \\
Total lipids & $6.67 \pm 0.15$ \\
Ash & $13.11 \pm 0.53$ \\
Carbohydrates & $18.10 \pm 0.69$ \\
\hline
\end{tabular}


Zagazig J. Agric. Res., Vol. 45 No. (1) 2018

Table 2. Fatty acids profile of Spirulina platensis spaghetti before cooking

\begin{tabular}{lcccc}
\hline Fatty acid & \multicolumn{4}{c}{ Fatty acid (\%) (Mean \pm SE) } \\
\cline { 2 - 5 } & Control & $\mathbf{0 . 5} \mathrm{g}$ & $\mathbf{1 . 0} \mathrm{g}$ & $\mathbf{2 . 0} \mathrm{g}$ \\
\hline $\mathbf{C 1 4 : 0}$ & $0.65 \pm 0.08$ & $1.31 \pm 0.04$ & $1.36 \pm 0.05$ & $1.93 \pm 0.04$ \\
$\mathbf{C 1 6 : 0}$ & $30.88 \pm 0.52$ & $34.37 \pm 0.11$ & $35.71 \pm 1.18$ & $36.52 \pm 0.11$ \\
$\mathbf{C 1 7 : 0}$ & $0.33 \pm 0.08$ & $0.56 \pm 0.06$ & $0.81 \pm 0.06$ & $0.90 \pm 0.06$ \\
$\mathbf{C 1 8 : 0}$ & $4.65 \pm 0.11$ & $7.96 \pm 0.03$ & $5.93 \pm 0.32$ & $7.30 \pm 0.83$ \\
$\mathbf{C 1 8 : 1}$ & $19.07 \pm 0.44$ & $19.84 \pm 0.41$ & $19.17 \pm 0.91$ & $22.23 \pm 1.04$ \\
$\mathbf{C 1 8 : 2}$ & $44.19 \pm 1.06$ & $33.37 \pm 0.75$ & $33.67 \pm 1.66$ & $27.27 \pm 0.55$ \\
$\mathbf{C 1 8 : 3 n 3}$ & -- & $2.17 \pm 0.15$ & $2.26 \pm 0.07$ & $2.38 \pm 0.15$ \\
$\mathbf{C}_{\mathbf{2 0}} \mathbf{H}_{\mathbf{3 2}} \mathbf{O}_{\mathbf{2}}$ & $0.05 \pm 0.03$ & $0.15 \pm 0.02$ & $0.72 \pm 0.06$ & $0.81 \pm 0.02$ \\
$\mathbf{C}_{\mathbf{2 2}} \mathbf{H}_{\mathbf{3} 4} \mathbf{O}_{\mathbf{2}}$ & $0.18 \pm 0.06$ & $0.27 \pm .08$ & $0.37 \pm 0.04$ & $0.66 \pm 0.01$ \\
\hline
\end{tabular}

$\mathrm{n}=3, \mathrm{p}<0.01$

Table 3. Fatty acids profile of Spirulina platensis Spaghetti after cooking

\begin{tabular}{lccc}
\hline Fatty acid & \multicolumn{3}{c}{ Fatty acid (\%) (Mean \pm S.E) } \\
\cline { 2 - 4 } & $\mathbf{0 . 5} \mathrm{g}$ & $\mathbf{1 . 0} \mathrm{g}$ & $\mathbf{2 . 0} \mathrm{g}$ \\
\hline $\mathbf{C 1 4 : 0}$ & $1.22 \pm 0.06$ & $1.3 \pm 0.03$ & $1.90 \pm 0.06$ \\
$\mathbf{C 1 6 : 0}$ & $33.89 \pm 1.12$ & $34.98 \pm 1.88$ & $31.29 \pm 0.23$ \\
$\mathbf{C 1 7 : 0}$ & $0.42 \pm 0.05$ & $0.59 \pm 0.04$ & $0.61 \pm 0.08$ \\
$\mathbf{C 1 8 : 0}$ & $4.48 \pm 0.09$ & $6.65 \pm 0.31$ & $6.93 \pm 0.33$ \\
$\mathbf{C 1 8 : 1}$ & $17.91 \pm 0.32$ & $17.61 \pm 0.52$ & $18.32 \pm 1.01$ \\
$\mathbf{C 1 8 : 2}$ & $40.08 \pm 0.63$ & $36.58 \pm 1.14$ & $38.26 \pm 0.53$ \\
$\mathbf{C 1 8 : 3 n 3}$ & $1.75 \pm 0.05$ & $1.89 \pm 0.05$ & $2.21 \pm 0.11$ \\
$\mathbf{C}_{\mathbf{2 0}} \mathbf{H}_{\mathbf{3 2}} \mathbf{O}_{\mathbf{2}}$ & $0.13 \pm 0.01$ & $0.23 \pm 0.06$ & $0.29 \pm 0.01$ \\
$\mathbf{C}_{\mathbf{2 2}} \mathbf{H}_{\mathbf{3 4}} \mathbf{O}_{\mathbf{2}}$ & $0.12 \pm .01$ & $0.17 \pm 0.01$ & $0.19 \pm 0.01$ \\
\hline
\end{tabular}

$\mathrm{n}=3, \mathrm{p}<0.01$

Common name of C14:0, Myristic acid; C16:0, Palmitic acid; C17:0, Margaric acid; C18:0, Stearic acid; C18:1, Oleic acid; $\mathrm{C} 18: 2$, Linoleic acid; $\mathrm{C} 18: 3, \gamma$ - Linolenic acid; $\mathrm{C}_{20} \mathrm{H}_{32} \mathrm{O}_{2}$, Arachidonic acid; $\mathrm{C}_{22} \mathrm{H}_{34} \mathrm{O}_{2}$, Docospapentaenic acid. 
Abd El-Hameed, et al.

Table 4. Sensory characteristics of Spirulina platensis spaghetti samples before and after cooking

\begin{tabular}{lcccccccc}
\hline Treatment & \multicolumn{3}{c}{ Before cooking } & \multicolumn{3}{c}{ After cooking } \\
\cline { 2 - 8 } & Colour & $\begin{array}{c}\text { Resistance } \\
\text { to break }\end{array}$ & $\begin{array}{c}\text { Overall } \\
\text { quality }\end{array}$ & Adhesiveness & Colour & Odour & Taste & $\begin{array}{c}\text { Overall } \\
\text { quality }\end{array}$ \\
\hline Control & $7.20 \pm 0.22$ & $6.25 \pm 0.2$ & $7.05 \pm 0.28$ & $6.20 \pm 0.40$ & $7.30 \pm 0.25$ & $7.30 \pm 0.25$ & $7.50 \pm 0.34$ & $7.35 \pm 0.4$ \\
$\mathbf{0 . 5}$ g S. platensis & $7.00 \pm 0.30$ & $6.91 \pm 0.25$ & $7.20 \pm 0.27$ & $6.22 \pm 0.40$ & $7.45 \pm 0.33$ & $7.35 \pm 0.40$ & $7.70 \pm 0.30$ & $7.60 \pm 0.30$ \\
$\mathbf{1 . 0}$ gS. platensis & $7.35 \pm 0.35$ & $7.25 \pm 0.24$ & $7.40 \pm 0.30$ & $6.60 \pm 0.25$ & $7.60 \pm 0.23$ & $7.52 \pm 0.25$ & $7.80 \pm 0.40$ & $7.67 \pm 0.25$ \\
$\mathbf{2 . 0}$ gS. platensis & $7.20 \pm 0.22$ & $7.32 \pm 0.34$ & $7.35 \pm 0.25$ & $6.80 \pm 0.30$ & $7.50 \pm 0.25$ & $7.02 \pm 0.25$ & $7.45 \pm 0.33$ & $7.20 \pm 0.34$ \\
\hline
\end{tabular}

\section{REFERENCES}

Alvarenga, R., B. Rodrigues, S. Cantarelli, G. Zangeronimo, S. Nior, R. Silva, M. Santos and J. Pereira (2011). Energy values and chemical composition of Spirulina (Spirulina platensis) evaluated with broilers. Res. Brasilian Zootechn., 40 (5): 992-996.

AOAC (2000). Association of Official Analytical Communities, Arlington, VA, USA, 74-103.

Belay, A. (2002). The potential application of spirulina (arthrospira) as a nutritional and therapeutic supplement in health management. J. Ame. Nutraceutical Ass., 5 (2): 1-24

Belch, J.J.F., D. Ansell, R. Madhok and R.D. Sturrock (1988). The effects of altering dietary essential fatty acids on requirements for non-steroidal anti-inflammatory drugs in patients with rheumatoid arthritis: a doubleblind placebo controlled study. Ann. Rheumatic Dis., 47:96-104.

Brennan, C.S., V. Kuri and C.M. Tudorica (2003). Inulin enriched pasta: effects on textural properties and starch degradation .Food Chem., 86: 189 - 193.

Chamorro, G., M. Salazar, K.G. Araujo, C.P. dos Santos, G. Ceballos and L.F. Castillo (2002). Update on the pharmacology of Spirulina (Arthrospira), an unconventional food." Arch Latinoam Nutr., 52 (3): 232-240.

Chillo, S., J. Laverse, P. Falcone and M. Del Nobile (2008). Quality of spaghetti in base amaranthus whole mealflour added with quinoa, broad bean and chick pea. J. Food Eng., 85 : 101-107.
Christie, W.W. (1993). Preparation of ester derivatives of fatty acids for chromatographic analysis. In: Advances in lipid methodologyTwo, pp. 69-111 William. W. Christie (Ed), Oily press, Dundee. The Scottish Crop Research Institute, Invergowrie, Dundee, Scotland DD2 5DA.

Costa, J.A.V., L.M Colla, D.P. Filho, K. Kabke and A. Weber (2002). Modelling of Spirulina platensis growth in fresh water using response surface methodology. World J. Microbiol. and Biotechnol, 18: 603-607.

Dan, W. and Q.W. KamilKuča (2016). Chapter 42-Spirulina Nutraceuticals Efficacy, Safety and Tox., 569-583.

Diraman, H., K. Edis and D. Hamdi (2009). Fatty acid profile of spirulina platensis used as a food supplement. J. Aquac., 62:134-142.

Edwards, N.M., M.S. Izydorczyk, J.E. Dexter and C.G. Biliaderis (1993). Cooked pasta texture: comparison of dynamic viscoelastic properties to instrumental assessment of firmness. Cereal Chem., 70 : 122 - 126.

Gerhardt, P., R. Murray, N. Costilow, W. Nester, A. Wood, R. Krieg and B. Phillips (1981). Manual of methods for general bacteriology. Ame. Soc. Microbiol. Washington, DC, 179- 207.

Guinea, G.V., F.J. Rojo and M. Elices (2004). Brittle failure of dry spaghetti. Eng. Failure Analysis, 11:705e714.

Kay, A. (1991). Microalgae as food and supplement Food Sci. Nutr., 30 (6): 555-573. 
Madkour, F.F., W. Kamil and H. Nasr (2012). Production and nutritive value of $S$. platensis in reduced cost media. Nat. Inst. Oceanography and Fish., Egypt. J. Aquatic Res., 38: 51-57.

Mbaiguinam, M., M. Tarkodjiel and N. Maoura (2006). Culture and comparison study of the chemical composition of blue algae of Kanem-Lake (Spirulina platensis). Ann. Univ. N'Djamena, C Series, Exact and Appl. Sci., $1: 10-21$.

Otles, S. and R. Pire (2001). Fatty acid composition of Chlorella and Spirulina microalgae species. J. AOAC Int., 84 (6): 1708 - 1714.

Padalino, L., M. Mastromatteo, L. Lecce, S. Spinelli, F. Conto and M.A. Del Nobile (2013). Chemical composition, sensory and cooking quality evaluation of durum wheat spaghetti enriched with pea flour. Int. J. Food Sci. and Technol., 49 : 1544-1556.

Petitot, M., C. Brossard, C. Barron, C. Larre, M.H. Morel and V. Micard (2009b). Modification of pasta structure induced by high drying temperatures: Effects on the in vitro digestibility of protein and starch fractions and the potential allergenicity of protein hydrolysates. Food Chem., 116: 401412.

Petitot, M., J. Abecassis and V. Micard (2009a). Structuring of pasta components during processing: Impact on starch and protein digestibility and allergenicity. Trends in Food Sci. and Technol., 20: 521-532.
Piorreck, M., H. Baasch and P. Pohl (1984). Biomass production, total protein, chlorophylls, lipids and fatty acids of freshwater Geen and blue-green algae under different nitrogen regimes Phytochem., 23 (2): 207-216.

Rakhesh, N., C.M. Fellows and M. Sissons (2015). Evaluation of the technological and sensory properties of durum wheat spaghetti enriched with different dietary fibres. J. Sci. Food and Agric., 95: 2-11.

Tudorica, C., M. Kuri and C.S. Brennan (2002). Nutritional and physicochemical characteristics of dietary fiber enriched pasta. J. Agric. and Food Chem., 50 : 347 - 356.

Vonshak, A. (1990). Recent advances in microalgae biotechnology. Biotech. Adv., 8: 709-727.

Vonshak, A., A. Abeliovich, S. Boussiba, S. Arad and A. Richmond (1982). Production of Spirulina Biomass: Effects of Environmental Factors and Population Density, Biomass., 2: 175-185.

Zarrouk, C. (1966). Contribution to the Cyanophyceae Study: Influence Various Physical and Chemical Factors on Growth and Photosynthesis of Spirulina Maxima (Setchet Gardner) Geither Extract. Ph. D. Thesis, Fac. Sci., Univ. Paris, 146.

Ziboh, V., A. and M.P. Fletcher (1992). Doseresponse effects of dietary gamma linolenic acid-enriched oils on human polymorphonuclear-neutrophil biosynthesis of leukotriene B4. Ame. J. Clin. Nutr., 55 : $39-45$. 
تأثيــر إضــافـة الإسبيرولينا (Spirulina platensis) على منتجـــات المكـرونــة (الاسباجيتي)

محمود خيري عبدالحميد - سامي محمد أبو المعاطي - سهير محمد السيد الصعيدي - سومية محمد أحمد

$$
\text { قسم علوم الأغذية ـ كلية الزر اعة - جامعة الزقازيق ـ مصر معرئ }
$$

يمكن اعتبار Spirulina platensis كبديل ومكون غذائي واعد بسبب تكوينها الغذائي ولأنها تعتبر مصدرا جيد

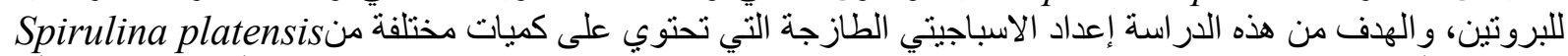

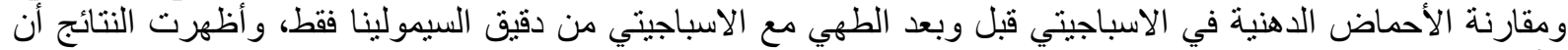

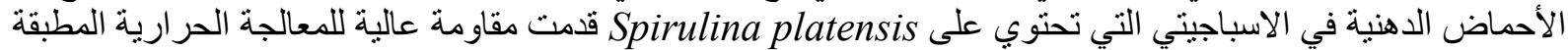
أثناء إجر اء الطهي، و أدت إضافة Spirulina platensis إلى الاسباجيتي إلى ارتفاع نسبة الأحماض الدهنية.

أستاذ الثروة السمكية - مركز البحوث الزراعية. أستاذ الصناعات الغذائية - كلية الزراعة النية - جامعة الزقازية. 